\title{
EFFECT OF ORAL SUPPLEMENTATION OF THE OPTIMIZED DOSE OF VITAMINS ON MILK YIELD, HAEMATOLOGICAL PARAMETERS AND UDDER HEALTH IN DEONI COWS
}

\author{
K. ASHWIN* AND B. SRINIVAS ${ }^{1}$ \\ Animal Nutrition Division \\ ICAR- Indian Veterinary Research Institute \\ Bareilly-243122, Uttar Pradesh, India
}

\begin{abstract}
A study was conducted to observe the effect of oral supplementation of optimized doses of vitamins on the somatic cell count (SCC), haematology and milk production in Deoni cows. Thirty-two Deoni cows (second parity) in their peak lactation (four weeks post-calving) were randomly divided into four groups $(\mathrm{n}=8)$ based on milk production $(3.17 \pm 0.18 \mathrm{~kg} / \mathrm{day})$ and fed with a basal diet $(\mathrm{CON})$ and/or supplemented with optimized doses of water-soluble (WS), fat-soluble (FS) vitamins, or both (WSFS). Oral dose of vitamins were optimized using in vitro gas production model and reported earlier. No significant influence of oral vitamin supplementation was observed on the milk yield, composition and haematology. However, the SCC reduced significantly $(P<0.05)$ with supplementation, with highest reduction in the WS group. The SCC values after the trial were higher compared to that before trial only in CON. The results underlined the influence of oral vitamin supplementation on the SCC and thereby udder health.
\end{abstract}

Key words: Cattle, Mastitis, Milk-composition, Milk-yield, Nutrition

India is the largest producer of milk in the world. This is primarily due to large population of cattle in the country, rather than higher productivity of the animals. Majority of the human population in India are vegetarians and their main source of high quality protein is milk. The major constraint for milk production in India is the unavailability of high quality forages. Any measure to improve the utilization of low quality forages by rumen microbiota can improve the nutrient status of the cow. Rumen microbes require specific vitamins for their proliferation (Ashwin et al., 2018). In an earlier study conducted in our laboratory, we had optimized the oral requirements of each vitamin for cattle for optimum rumen microbial proliferation through in vitro studies, and validated it in vivo in Deoni cows (Kandathil and Srinivas, 2019). The present study was conducted to validate the effect of optimized

*Corresponding Author

${ }^{1}$ Dairy Production Section, Southern Regional Station, ICAR- National Dairy Research Institute, Adugodi, Banglore- 560030 
oral supplementation of vitamins on milk yield, composition and SCC. Apart from this, the effect of supplementation on haematology was also assessed.

\section{MATERIALS AND METHODS}

Animals, experimental design, diets: The study was carried out at Deoni conservation farm, National Dairy Research Institute, Bengaluru, India. Thirty-two milking Deoni cows (second parity) in their peak lactation (four week post-calving) were selected. They were randomly divided into four groups $(\mathrm{n}=8)$ based on average milk production at fourth week postcalving $(3.17 \pm 0.18 \mathrm{~kg} /$ day $)$. The treatments were: (i) basal diet with no vitamins (CON), or supplemented with the optimized dose of (ii) water-soluble (WS), (iii) fat-soluble vitamins (FS), or (iv) both (WSFS). Basal diet in the study consisted of concentrate mixture and Finger millet (Elusine coracana) straw in 30:70 ratio. The concentrate used for the present study contained 25 parts maize, 25 parts de-oiled rice bran, 15 parts molasses, 12 parts cotton seed cake, 11 parts soya bean meal, 9 parts de-oiled copra cake, 2 part mineral mixture and 1 part common salt. The nutrient composition of concentrate (mean $\pm \mathrm{SE}$, in percentage) were $16.84 \pm 0.33$ crude protein $(\mathrm{CP}), 3.48 \pm 0.21$ ether extract (EE), 8.85 \pm 0.09 total ash (TA), $1.38 \pm 0.06$ acid insoluble ash (AIA), $70.84 \pm 0.19$ total carbohydrate and $91.15 \pm 0.09$ organic matter (OM). For finger millet straw the $\mathrm{CP}$, EE, TA, AIA, TCHO and OM were respectively $5.44 \pm 0.51,1.36 \pm 0.09,9.08 \pm 0.12,2.32 \pm 0.08$, $84.13 \pm 0.54$ and $90.92 \pm 0.12$ percentage. The nutrient requirements of the animals were calculated based on Indian Council of Agricultural Research guidelines (ICAR, 2013).
Dose of vitamins optimized in an earlier study conducted in our laboratory was used in the present study (Kandathil and Srinivas, 2019), which was 3.66, 6.78, 16.3, 41.1, 3.87, 0.323, 4.12 and $0.055 \mathrm{mg} / \mathrm{kg}$ DM intake for thiamine, riboflavin, niacin, pantothenic acid, pyridoxine, biotin, folic acid and $\mathrm{B}_{12}$ respectively. Among FS vitamins, only vitamin $\mathrm{K}$ was observed as essential for optimal rumen fermentation at a dose rate of $500 \mathrm{IU} / \mathrm{kg}$ DM intake. All the animals were dewormed using fenbendazole before the start of experiment.

\section{Experimental protocol and sampling:} Experimental feeding was carried out for a period of 45 days. Five milliliter of blood was collected in ethylene diamine tetraacetic acid (EDTA) coated vials at the beginning (after the adjustment period), and at the end of the digestibility trial. Feed was weighed and offered individually to cows twice daily at $9 \mathrm{AM}$ and 5 PM. Drinking water was offered ad libitum. Daily milk yield (MY) was recorded throughout the experiment duration. Change in the MY with oral vitamin supplementation was calculated by subtracting initial reading from weekly average MY for up to five weeks. Milk samples from cows were collected twice a week in morning and evening, and were pooled for milk fat (MF) and solid non-fat (SNF) estimation. The SCC was estimated after adjustment period, and at the end of the digestibility trial. The difference in SCC before and after experimental feeding was calculated for each treatment.

Chemical analyses: Milk fat (MF; AOAC, 2000; Method 2000.18) and total solids (TS; AOAC, 2000; Method 925.23) were calculated on the same day of collection using standard protocols. The SNF was calculated as the difference between TS and MF. 
The somatic cell count (SCC) in the milk before and after the experimental feeding was estimated using digital reader (M/S Porta Check Inc., USA). A drop of well mixed sample of milk was taken using a sterile pipette and was added to the sample well of the Porta-strip. Three drops of activator solution was added to this, and it was kept for 30 to 45 minutes at room temperature for colour development. The strip after incubation was inserted to the digital reader to get the reading.

Haematological parameters were estimated within 2 hour of collection using autohaematology analyzer (BC-2800 Vet, M/S Mindray Medical International Ltd, Shenzen, China). Haematological parameters studied were haemoglobin $(\mathrm{Hb} ; \mathrm{g} / \mathrm{dL})$, packed cell volume (PCV; \%), erythrocytes (RBC; $\times 10^{6} \%$ $\mu \mathrm{L}$ ), leukocytes (WBC; $\times 10^{3} / \mu \mathrm{L}$ ), lymphocytes $\left(\times 10^{3} / \mu \mathrm{L}\right)$, monocytes $\left(\times 10^{3} / \mu \mathrm{L}\right)$, granulocytes $\left(\times 10^{3} / \mu \mathrm{L}\right)$, platelets $\left(\times 10^{3} / \mu \mathrm{L}\right)$, monocyte $(\%)$, lymphocyte $(\%)$ and granulocyte $(\%)$.

Statistical analyses: The results obtained were subjected to analysis of variance and are presented as means with standard error of means (SEMs). Univariate analysis was carried out with treatment and period as fixed factors and respective statistic as dependent variable using SPSS v 20.0. Post hoc comparisons were performed using Tukey test. The SCC before and, after experimental feeding were analyzed using paired $\mathrm{T}$ test. The difference between means was considered statistically significant at $5 \%$ level of probability $(\mathrm{P} \leq 0.05)$.

\section{RESULTS}

Weekly change in MY, MF and SNF are given in Table 1. There was no significant change in the milk yield with vitamin supplementation $(\mathrm{P}>0.05)$. Temporal changes in MY was also not significant $(\mathrm{P}>0.05)$. Solid non-fat $(\mathrm{SNF})$ content of milk was not significantly different between groups. Milk fat content was significantly higher with FS supplementation (5.43\%) compared to WS and WSFS (4.36 and $4.61 \%$ respectively), whereas it was intermediate in CON (4.90\%). This data is not conclusive as the initial MF (before the start of trial) varied between groups.

Temporal variation in PCV, TEC, granulocyte, platelets and lymphocyte were significant $(\mathrm{P}<0.05$; Table 2). However, no effect of vitamin supplementation was observed in haematology $(\mathrm{P}>0.05)$.

The initial SCC of different treatment groups varied from 57500 cells $/ \mathrm{mL}$ in WSFS to 105000 cells $/ \mathrm{mL}$ in WS (Table 3). Paired Ttest was used to compare the effect of supplementations on the SCC. In CON, the SCC showed an increasing trend $(\mathrm{P}=0.08)$ after trial compared to the corresponding reading before experimental feeding. In WS group, a decreasing trend with supplementation was obvious ( 105000 vs 80000 cells $/ \mathrm{mL} ; \mathrm{P}=0.063$ ). With FS and WSFS supplementation, no such trends were observed on the SCC ( $>0.1)$. As the initial SCC before start of experimental feeding were not uniform among groups, the difference before and after trial was calculated and compared (Fig. 1).There was a significant reduction in the SCC in all treatment groups compared to $\mathrm{CON}(\mathrm{P}=0.022)$. The highest reduction in SCC was observed with WS supplementation, the reduction was intermediate in FS and WSFS groups, whereas SCC increased only in CON. 
Table 1. Weekly changes in the milk yield (MY), milk fat (MF) and solid-non-fat (SNF) in lactating Deoni cows supplemented orally with optimized doses of water-soluble (WS), fat-soluble (FS) or both (WSFS) vitamins vis-à-vis control (CON)

\begin{tabular}{|c|c|c|c|c|c|c|c|c|c|c|}
\hline \multirow{2}{*}{ 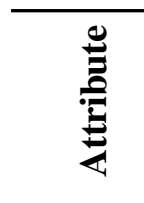 } & \multirow{2}{*}{ 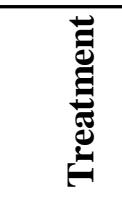 } & \multicolumn{6}{|c|}{ Period } & \multirow{2}{*}{ 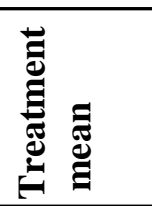 } & \multirow[b]{2}{*}{ SEM } & \multirow[b]{2}{*}{ P value } \\
\hline & & Owk & 1wk & $2 w k$ & 3wk & $4 w k$ & $5 w k$ & & & \\
\hline \multirow{5}{*}{$\begin{array}{l}\text { Change } \\
\text { in milk } \\
\text { yield }\end{array}$} & $\mathrm{CON}$ & 0.00 & 0.06 & 0.10 & 0.32 & 0.41 & 0.26 & 0.19 & \multirow{5}{*}{$\begin{array}{l}\mathrm{T}=0.061 \\
\mathrm{P}=0.074 \\
\mathrm{~T} \times \mathrm{P}=0.148\end{array}$} & \multirow{5}{*}{$\begin{array}{l}\mathrm{T}=0.393 \\
\mathrm{P}=0.384 \\
\mathrm{~T} \times \mathrm{P}=0.986\end{array}$} \\
\hline & WS & 0.00 & 0.04 & 0.06 & 0.11 & 0.11 & 0.17 & 0.08 & & \\
\hline & FS & 0.00 & 0.08 & 0.18 & 0.06 & 0.09 & -0.09 & 0.05 & & \\
\hline & WSFS & 0.00 & 0.03 & 0.13 & 0.19 & 0.24 & 0.19 & 0.13 & & \\
\hline & $\begin{array}{l}\text { Period } \\
\text { mean }\end{array}$ & 0.00 & 0.05 & 0.11 & 0.17 & 0.21 & 0.13 & 10.37 & & \\
\hline \multirow{5}{*}{$\begin{array}{l}\text { Milk } \\
\text { SNF }\end{array}$} & $\mathrm{CON}$ & 10.37 & 10.42 & 9.81 & 9.50 & 9.35 & 9.97 & \multirow{5}{*}{$\begin{array}{c}9.52 \\
10.10 \\
9.64\end{array}$} & \multirow{5}{*}{$\begin{array}{l}\mathrm{T}=0.180 \\
\mathrm{P}=0.221 \\
\mathrm{~T} \times \mathrm{P}=0.442\end{array}$} & \multirow{5}{*}{$\begin{array}{l}\mathrm{T}=0.089 \\
\mathrm{P}=0.008 \\
\mathrm{~T} \times \mathrm{P}=0.998\end{array}$} \\
\hline & WS & 10.41 & 9.88 & 9.31 & 8.99 & 9.18 & 9.34 & & & \\
\hline & FS & 10.68 & 10.52 & 10.25 & 9.71 & 9.52 & 9.90 & & & \\
\hline & WSFS & 10.11 & 9.78 & 9.75 & 9.48 & 9.36 & 9.38 & & & \\
\hline & $\begin{array}{l}\text { Period } \\
\text { mean }\end{array}$ & $10.39^{b}$ & $10.14^{\mathrm{ab}}$ & $9.93^{\mathrm{ab}}$ & $9.50^{\mathrm{ab}}$ & $9.39^{\mathrm{a}}$ & $9.49^{\mathrm{ab}}$ & & & \\
\hline \multirow{5}{*}{ Milk fat } & $\mathrm{CON}$ & 4.45 & 4.74 & 4.81 & 4.91 & 5.15 & 5.35 & $4.90^{\mathrm{ab}}$ & $\mathrm{T}=0.215$ & $\mathrm{~T}=0.005$ \\
\hline & WS & 4.35 & 4.42 & 4.38 & 4.29 & 4.20 & 4.50 & $4.36^{\mathrm{a}}$ & $\mathrm{P}=0.263$ & $\mathrm{P}=0.696$ \\
\hline & FS & 5.02 & 5.16 & 5.22 & 5.59 & 5.73 & 5.87 & $5.43^{\mathrm{b}}$ & \multirow[t]{3}{*}{$\mathrm{T} \times \mathrm{P}=0.527$} & \multirow[t]{3}{*}{$\mathrm{T} \times \mathrm{P}=1$} \\
\hline & WSFS & 4.34 & 4.46 & 4.64 & 4.73 & 4.74 & 4.75 & $4.61^{\mathrm{a}}$ & & \\
\hline & $\begin{array}{l}\text { Period } \\
\text { mean }\end{array}$ & 4.54 & 4.69 & 4.76 & 4.88 & 4.96 & 5.12 & & & \\
\hline
\end{tabular}

${ }^{\mathrm{ab}}$ Means bearing different superscripts differ significantly according to Tukey test $(\mathrm{P}<0.05)$

Table 2. Haematological values in lactating Deoni cows supplemented orally with optimized doses of water-soluble (WS), fat-soluble (FS) or both (WSFS) vitamins

\begin{tabular}{lllllll}
\hline \multirow{2}{*}{ Attributes } & & 0d & 45d & Treatment & SEM & P value \\
& & & & mean & & \\
\hline $\mathrm{Hb}(\mathrm{g} / \mathrm{dL})$ & CON & 12.18 & 11.33 & 11.75 & $\mathrm{~T}=0.248$ & $\mathrm{~T}=0.138$ \\
& WS & 11.60 & 10.95 & 11.28 & $\mathrm{P}=0.175$ & $\mathrm{P}=0.164$ \\
& FS & 11.90 & 12.00 & 11.95 & $\mathrm{~T} \times \mathrm{P}=0.351$ & $\mathrm{~T} \times \mathrm{P}=0.167$ \\
& WSFS & 11.25 & 11.23 & 11.24 & & \\
& Period mean & 11.73 & 11.38 & & & \\
\hline
\end{tabular}


Cont. Table- 2.

\begin{tabular}{|c|c|c|c|c|c|c|}
\hline \multirow{2}{*}{ Attributes } & & \multicolumn{2}{|c|}{ Period } & \multirow[b]{2}{*}{$\begin{array}{l}\text { Treatment } \\
\text { mean }\end{array}$} & \multirow[b]{2}{*}{ SEM } & \multirow[b]{2}{*}{$P$ value } \\
\hline & & Od & $45 d$ & & & \\
\hline \multirow[t]{5}{*}{$\overline{\mathrm{PCV}(\%)}$} & CON & 34.60 & 36.05 & 35.33 & $\mathrm{~T}=0.254$ & $\mathrm{~T}=0.154$ \\
\hline & WS & 33.00 & 35.30 & 34.15 & $\mathrm{P}=0.179$ & $\mathrm{P}=0.001$ \\
\hline & FS & 34.13 & 39.30 & 36.71 & $\mathrm{~T} \times \mathrm{P}=1.24$ & $\mathrm{~T} \times \mathrm{P}=0.446$ \\
\hline & WSFS & 32.15 & 36.20 & 34.18 & & \\
\hline & Period mean & $33.47^{\mathrm{a}}$ & $36.71^{\mathrm{b}}$ & & & \\
\hline \multirow{5}{*}{$\begin{array}{l}\text { TEC }\left(\times 10^{6} /\right. \\
\mu \mathrm{L})\end{array}$} & $\mathrm{CON}$ & 6.78 & 7.93 & 7.35 & $\mathrm{~T}=0.254$ & $\mathrm{~T}=0.52$ \\
\hline & WS & 6.45 & 7.20 & 6.83 & $\mathrm{P}=0.179$ & $\mathrm{P}<0.001$ \\
\hline & FS & 6.48 & 7.88 & 7.18 & $\mathrm{~T} \times \mathrm{P}=0.360$ & $\mathrm{~T} \times \mathrm{P}=0.841$ \\
\hline & WSFS & 6.65 & 7.78 & 7.21 & & \\
\hline & Period mean & $6.59^{\mathrm{a}}$ & $7.69^{\mathrm{b}}$ & & & \\
\hline \multirow{5}{*}{$\begin{array}{l}\text { TLC }\left(\times 10^{3} /\right. \\
\mu \mathrm{L})\end{array}$} & $\mathrm{CON}$ & 10.63 & 9.95 & 10.29 & $\mathrm{~T}=0.742$ & $\mathrm{~T}=0.901$ \\
\hline & WS & 11.45 & 10.58 & 11.01 & $\mathrm{P}=0.525$ & $\mathrm{P}=0.752$ \\
\hline & FS & 10.08 & 11.25 & 10.66 & $\mathrm{~T} \times \mathrm{P}=1.049$ & $\mathrm{~T} \times \mathrm{P}=0.747$ \\
\hline & WSFS & 10.68 & 10.10 & 10.39 & & \\
\hline & Period mean & 10.71 & 10.47 & & & \\
\hline \multirow{5}{*}{$\begin{array}{l}\text { Lymphocyte } \\
\left(\times 10^{3} / \mu \mathrm{L}\right)\end{array}$} & $\mathrm{CON}$ & 4.53 & 5.25 & 4.89 & $\mathrm{~T}=0.519$ & $\mathrm{~T}=0.745$ \\
\hline & WS & 5.30 & 5.68 & 5.49 & $\mathrm{P}=0.367$ & $\mathrm{P}=0.078$ \\
\hline & FS & 4.60 & 5.60 & 5.10 & $\mathrm{~T} \times \mathrm{P}=0.734$ & $\mathrm{~T} \times \mathrm{P}=0.822$ \\
\hline & WSFS & 3.85 & 5.58 & 4.71 & & \\
\hline & Period mean & 4.57 & 5.53 & & & \\
\hline \multirow{5}{*}{$\begin{array}{l}\text { Monocyte } \\
\left(\times 10^{3} / \mu \mathrm{L}\right)\end{array}$} & $\mathrm{CON}$ & 0.95 & 0.80 & 0.88 & $\mathrm{~T}=0.107$ & $\mathrm{~T}=0.778$ \\
\hline & WS & 0.88 & 0.78 & 0.83 & $\mathrm{P}=0.076$ & $\mathrm{P}=0.390$ \\
\hline & FS & 0.80 & 1.10 & 0.95 & $\mathrm{~T} \times \mathrm{P}=0.152$ & $\mathrm{~T} \times \mathrm{P}=0.149$ \\
\hline & WSFS & 1.18 & 0.75 & 0.96 & & \\
\hline & Period mean & 0.95 & 0.86 & & & \\
\hline \multirow{5}{*}{$\begin{array}{l}\text { Granulocyte } \\
\left(\times 10^{3} / \mu \mathrm{L}\right)\end{array}$} & $\mathrm{CON}$ & 5.15 & 3.90 & 4.53 & $\mathrm{~T}=0.443$ & $\mathrm{~T}=0.99$ \\
\hline & WS & 5.28 & 4.13 & 4.70 & $\mathrm{P}=0.313$ & $\mathrm{P}=0.02$ \\
\hline & FS & 4.68 & 4.55 & 4.61 & $\mathrm{~T} \times \mathrm{P}=0.626$ & $\mathrm{~T} \times \mathrm{P}=0.579$ \\
\hline & WSFS & 5.65 & 3.78 & 4.71 & & \\
\hline & Period mean & $5.19^{\mathrm{a}}$ & $4.09^{\mathrm{b}}$ & & & \\
\hline
\end{tabular}


Cont. Table- 2.

\begin{tabular}{lllllll}
\hline \multirow{2}{*}{ Attributes } & & Od & 45d & $\begin{array}{l}\text { Treatment } \\
\text { mean }\end{array}$ & SEM & P value \\
\hline Platelets & CON & 552.5 & 309.0 & 430.75 & $\mathrm{~T}=63.58$ & $\mathrm{~T}=0.138$ \\
$\left(\times 10^{3} / \mu \mathrm{L}\right)$ & WS & 526.3 & 237.3 & 381.75 & $\mathrm{P}=44.96$ & $\mathrm{P}<0.001$ \\
& FS & 766.5 & 327.8 & 547.13 & $\mathrm{~T} \times \mathrm{P}=89.92$ & $\mathrm{~T} \times \mathrm{P}=0.728$ \\
& WSFS & 720.3 & 417.8 & 569.00 & & \\
& Period mean & $641.4^{\mathrm{a}}$ & $322.9^{\mathrm{b}}$ & & & \\
\hline Lymphocyte & CON & 42.050 & 52.075 & 47.063 & $\mathrm{~T}=3.268$ & $\mathrm{~T}=0.847$ \\
$(\%)$ & WS & 45.375 & 53.375 & 49.375 & $\mathrm{P}=2.311$ & $\mathrm{P}=0.004$ \\
& FS & 45.900 & 50.800 & 48.350 & $\mathrm{~T} \times \mathrm{P}=4.622$ & $\mathrm{~T} \times \mathrm{P}=0.476$ \\
& WSFS & 35.950 & 54.950 & 45.450 & & \\
\hline Monocyte & Period mean & $42.319^{\mathrm{a}}$ & $52.80^{\mathrm{b}}$ & & & \\
\hline & CON & 8.950 & 8.325 & 8.638 & $\mathrm{~T}=0.635$ & $\mathrm{~T}=0.283$ \\
& WS & 7.750 & 7.600 & 7.675 & $\mathrm{P}=0.449$ & $\mathrm{P}=0.321$ \\
& FS & 8.200 & 9.725 & 8.963 & $\mathrm{~T} \times \mathrm{P}=0.898$ & $\mathrm{~T} \times \mathrm{P}=0.083$ \\
& WSFS & 11.075 & 7.750 & 9.413 & & \\
\hline Granulocyte & CON & 49.000 & 39.600 & 44.300 & $\mathrm{~T}=3.017$ & $\mathrm{~T}=0.932$ \\
$(\%)$ & WS & 46.875 & 39.050 & 42.963 & $\mathrm{P}=2.133$ & $\mathrm{P}=0.003$ \\
& FS & 45.900 & 39.475 & 42.688 & $\mathrm{~T} \times \mathrm{P}=4.267$ & $\mathrm{~T} \times \mathrm{P}=0.715$ \\
& WSFS & 52.975 & 37.300 & 45.138 & & \\
& Period mean & $48.688^{\mathrm{b}}$ & $38.856^{\mathrm{a}}$ & & & \\
\hline
\end{tabular}

${ }^{\mathrm{ab}}$ Means with different superscripts differ significantly according to Tukey test $(\mathrm{P}<0.05)$

Table 3. Somatic cell count (SCC, cells/mL) of milk in lactating Deoni cows before ( 0 day) vs. after (45 day) supplementation with water-soluble (WS), fat-soluble (FS) or both vitamins (WSFS) vis-à-vis control (CON)

\begin{tabular}{lrclc}
\hline Treatments & Period & Mean SCC & SEM & P value \\
\hline CON & Od & 60000 & 10000 & 0.08 \\
& $45 \mathrm{~d}$ & 72500 & 13150 & \\
\hline WS & Od & 105000 & 19365 & 0.063 \\
& $45 \mathrm{~d}$ & 80000 & 10801 & \\
\hline FS & $0 \mathrm{~d}$ & 77500 & 10308 & \multirow{2}{*}{0.252} \\
& $45 \mathrm{~d}$ & 67500 & 10308 & \\
\hline WSFS & Od & 57500 & 7500 & 0.391 \\
& $45 \mathrm{~d}$ & 50000 & 0 & \\
\hline
\end{tabular}




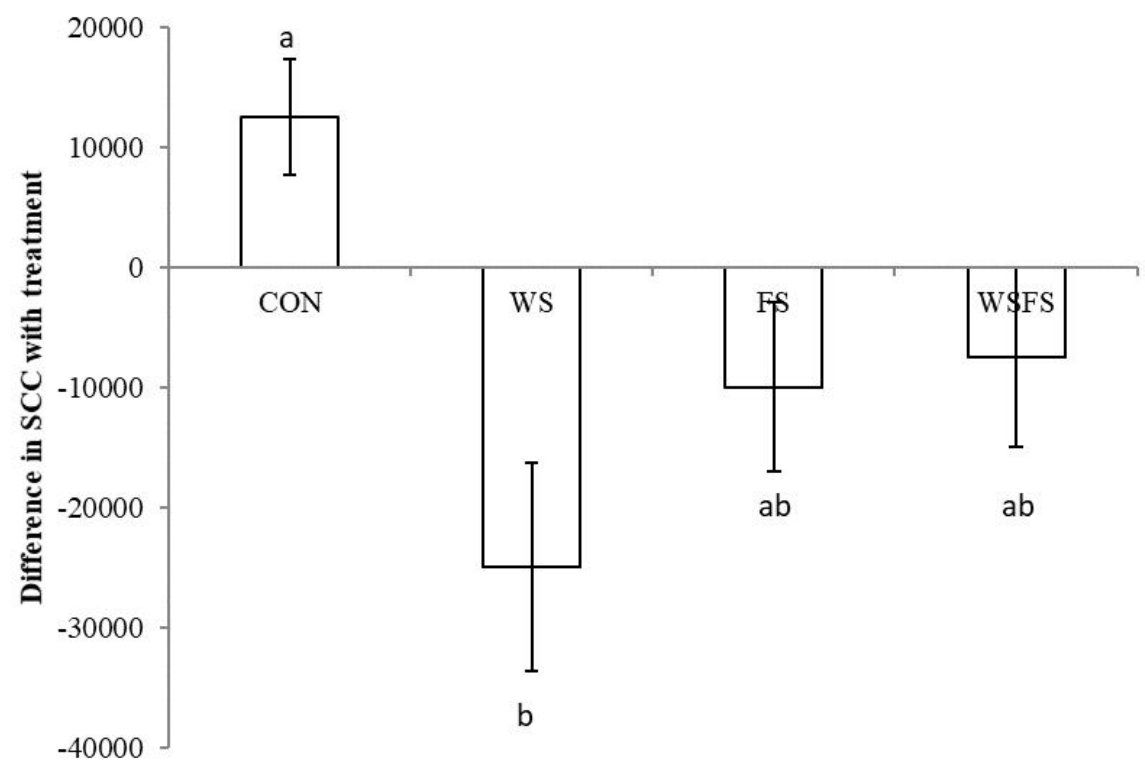

${ }^{\mathrm{ab}}$ Means bearing different superscripts differ significantly between groups according to Tukey test

Fig. 1. Difference in the somatic cell count (SCC) of milk (mean \pm SEM) in lactating Deoni cows after supplementation with water-soluble (WS), fat-soluble (FS) or both vitamins (WSFS) vis-à-vis control (CON)

\section{DISCUSSION}

Oral supplementation of an optimized dose of vitamins showed higher rumen microbial protein synthesis in an earlier study conducted in our laboratory (Kandathil and Srinivas, 2019). Hence, we hypothesized that an increase in microbial protein supply would improve the nutrient status of the animal and ultimately result in higher MY. However, in the present study, we could not observe any effect of oral supplementation on the MY. The primary reason for the absence of supplementation effects may be the inherent low productivity of Deoni cows. Studies conducted in high producing cows showed increase in milk yield with vitamin A (Oldham et al., 1991; De-
Ondarza et al., 2009), vitamin D (Hibbs and Conrad, 1983), thiamin (Bal et al., 2000); niacin (Tamizrad and Karkoodi, 2009); folic acid (Girard and Matte, 1998); vitamin $B_{12}$ (Graulet et al., 2007) and biotin (Midla et al., 1998; Bergsten et al., 2003) supplementations. On the contrary, Rahmani et al. (2014) and Fitzgerald et al. (2000) failed to observe any effect of oral supplementation of vitamin $\mathrm{E}$ and biotin respectively in the MY. The results from most of the experiments were inconsistent and varying in nature. However, higher productivity was observed in most cases supplemented with folic acid, vitamin $B_{12}$ and choline. This may be mainly attributed to the methyl group 
donating property of these compounds. Often, methionine is the limiting amino acid for the synthesis of microbial protein in the rumen. Supply of methyl group may improve the quality of microbial protein synthesized, eventually resulting in higher nutritional status of the animal and higher productivity.

Somatic cell count is widely used to monitor udder health worldwide (Sharif and Muhammad, 2008). The SCC mainly consists of milk secreting epithelial cells and leukocytes that shed/enter the mammary gland following infections (Jones, 2006; Sharma et al., 2011). The Deoni cows selected for the present study showed an initial SCC reading ranging from 57500 to 105000 cells/ $\mathrm{mL}$. The normal SCC values of Deoni breed of cows have not been published yet at best of our knowledge. Earlier reports indicated increase in the SCC with age (Blackburn, 1966) which was mainly due to increased prevalence of infections in older cows (Sharma et al., 2011). In our present study we had selected only cows of similar parity to reduce such an error. The normal SCC in high producing cattle breeds like Brown Swiss and Holstein Friesian were reported as $423 \times 10^{3}$ and $310 \times 10^{3}$ cells $/ \mathrm{mL}$ respectively in an earlier study (Sharma et al., 2011). Among Indian breeds, the average SCC $\left(\times 10^{3}\right.$ cells $\left./ \mathrm{mL}\right)$ of studied herds of Tharparker, Sahiwal, Karan Fries and Karan Swiss were 1.26, 1.31, 1.61 and 1.54 respectively (Singh, 2002). The initial average SCC in the Deoni cows selected for the study was 75000 cells $/ \mathrm{mL}$. In the present study, the highest reduction in the SCC posttreatment was observed in WS group, whereas reduction was intermediate in FS and WSFS groups. Absence of additive effect of WS and FS supplementation in the reduction of SCC cannot be concluded from the present study as the SCC reduced to minimum detectable levels ( 50000 cells $/ \mathrm{mL})$ with WSFS supplementation. In the present experiment, none of the groups had SCC required for concluding clinical mastitis $(<200000$ cells $/ \mathrm{mL})$. A reduction in stress with vitamin supplementation was assumed as the possible reason for the reduction in milk SCC.

Haematological parameters are generally used to evaluate the nutritional status of the animals. This is also used as an indicator to study the effect of nutritional supplementation (Cherdthong et al., 2014). We could not find any study correlating B complex vitamin supplementation with haematological parameters in dairy cows. In neonatal calves, supplementation of vitamin A for first five days significantly improved $\mathrm{Hb}$ concentration by affecting iron metabolism (Moosavian et al., 2010). On the contrary, no such effect was observed by Kume and Toharmat (2001). Vitamin E supplementation improved blood leukocyte concentration in many studies (Bednarek et al., 1996; Mohri et al., 2005). No reports correlating vitamin $\mathrm{K}$ supplementation with haematology in dairy cows were available. However, in our present study we supplemented only vitamin K among FS vitamins. In the present study, no influence of vitamin supplementation was observed on the haematology parameters. The temporal change in certain haematological parameters may be due to deprivation of green fodder and thereby certain micronutrients during the entire experimental feeding period.

The study concluded that the supplementation of optimized doses of WS vitamins alone or in 
combination with FS (WSFS) had a beneficial role in promoting udder health as evident from the extent of reduction in the SCC. Further experiments with high producing animals are required to validate the effect of oral supplementation of vitamins on the yield of milk and its constituents.

Conflict of interest: The authors declare that

\section{REFERENCES}

AOAC. Official Methods of Analysis. 17th edn., Gaithersburg, MD, USA: Association of Official Analytical Chemists; 2000

Ashwin K, Paladan V, Uniyal S, Sahoo JK, Perween $\mathrm{S}$ et al., 2018. An update on B vitamin nutrition for cattle. Int J Curr Microbiol App Sci, 7(07): 188-192

Bal MA, Shaver RD, Jirovec AG, Shinners KJ and Coors JG, 2000. Crop processing and chop length of corn silage: Effects on intake, digestion, and milk production by dairy cows. J Dairy Sci, 83(6): 1264-1273

Bednarek D, Kondracki M and Cakala S, 1996. Effect of selenium and vitamin $\mathrm{E}$ on white cells, serum concentration of several minerals and trace elements as well as immunologic parameters in calves. Dtsch Tierarztl Wochenschr, 103(11): 457-459

Bergsten C, Greenough PR, Gay JM, Seymour WM and Gay CC, 2003. Effects of biotin supplementation on performance and claw lesions on a commercial dairy farm. J Dairy Sci, 86(12): 3953-3962

Blackburn PS, 1966. The variation in cell count of cow's milk throughout lactation and from one lactation to the next. J Dairy Res, 33:193-198 there is no conflict of interest regarding the present research work.

\section{ACKNOWLEDGEMENT}

The present study was a part of the M.V.Sc research of the first author, utilizing institutional funds of the National Dairy Research Institute, Karnal, India.

Cherdthong A, Wanapat M, Rakwongrit D, Khota W, Khantharin S et al., 2014. Supplementation effect with slow-release urea in feed blocks for Thai beef cattle-nitrogen utilization, blood biochemistry, and hematology. Trop Anim Health Pro, 46(2): 293-298

De-Ondarza MB, Wilson JW and Engstrom M, 2009. Case study: Effect of supplemental $\beta$-carotene on yield of milk and milk components and on reproduction of dairy cows. Professional Anim Scientist, 25(4): 510-516

Fitzgerald T, Norton BW, Elliott R, Podlich $\mathrm{H}$ and Svendsen OL, 2000. The influence of long term supplementation with biotin on the prevention of lameness in pasture fed dairy cows. J Dairy Sci, 83: 338-344

Girard CL and Matte JJ, 1998. Dietary supplements of folic acid during lactation: effects on the performance of dairy cows. J Dairy Sci, 81(5): 1412-1419

Graulet B, Matte JJ, Desrochers A, Doepel L, Palin MF et al., 2007. Effects of dietary supplements of folic acid and vitamin $B_{12}$ on metabolism of dairy cows in early lactation. $\mathrm{J}$ Dairy Sci, 90(7): 3442-3455 
Hibbs JW and Conrad HR, 1983. The relation of calcium and phosphorus intake and digestion and the effects of vitamin D feeding on the utilization of calcium and phosphorus by lactating dairy cows. Ohio Agric Expt Stn Wooster, Ohio State University

Jones GM, 2006. Understanding the basics of mastitis. Virginia Cooperative Extension, Publication No. 404-233. Virginia State Univ. Press, Virginia, USA, pp1-7

Kandathil A and Srinivas B, 2019. Optimized oral supplementation of vitamins improves feed intake and rumen microbial protein synthesis in Deoni cows. Turk J Anim Vet Sci, 43(2): 197-205

Kume S and Toharmat T, 2001. Effect of colostral b-carotene and vitamin A on vitamin and health status of newborn calves. Live Pro Sci, 68: $61-65$

MidlaLT, Hoblet KH, Weiss WP and Moeschberger ML, 1998. Supplemental dietary biotin for prevention of lesions associated with aseptic subclinical laminitis (pododermatitis aseptica diffusa) in primiparous cows. Am J Vet Res, 59: 733-738

Mohri M, Seifi HA and Khodadadi J, 2005. Effects of preweaning parenteral supplementation of vitamin E and selenium on hematology, serum proteins, and weight gain in dairy calves. Comp Clin Path, 14(3): 149-154

Moosavian HR, Mohri M and Seifi HA, 2010. Effects of parenteral over-supplementation of vitamin A and iron on hematology, iron biochemistry, weight gain, and health of neonatal dairy calves. Food Chem Toxicol, 48(5): 1316-1320

Oldham ER, Eberhart RJ and Muller LD, 1991. Effects of Supplemental vitamin A or B carotene during the dry period and early lactation on udder health. J Dairy Sci, 74: 3775-3781

Rahmani M, Deghan-Banadaky and Kamalyan R, 2014. Effects of feeding rumen protected choline and vitamin $\mathrm{E}$ on milk yield, milk composition, dry matter intake, body condition score and body weight in early lactating dairy cows. Iran J Appl Anim Sci, 4: 693-698

Sharif A and Muhammad G, 2008. Somatic cell count as an indicator of udder health status under modern dairy production: A review. Pak Vet J, 28(4): 194-200

Sharma N, Singh NK and Bhadwal MS, 2011. Relationship of somatic cell count and mastitis: An overview. Asian-Australas J Anim Sci, 24(3): 429-438

Singh M, 2002. Somatic cell counts during lactation in bovines as a index of subclinical mastitis. Proceedings of all India dairy husbandry officers workshop NDRI, Karnal (India), pp 64-77

Tamizrad K and Karkoodi K, 2009. Effect of niacin supplementation on performance and blood parameters of Holstein cows. S Afr J Anim Sci, 39(4): 349-354 